\title{
Clinical studies on posterior cruciate ligament tears have weak design
}

\author{
Anne Marie Eriksen Watsend - Toril M. Ø. Osestad • \\ Rune B. Jakobsen · Lars Engebretsen
}

Published online: 9 January 2009

(C) Springer-Verlag 2008

\section{Erratum to: Knee Surg Sports Traumatol Arthrosc} DOI 10.1007/s00167-008-0632-9

Unfortunately, the family name of the third author has been given incorrectly in the article. It should be Jakobsen as now given above and below.

The online version of the original article can be found under doi:10.1007/s00167-008-0632-9.

\footnotetext{
A. M. E. Watsend - T. M. Ø. Osestad - R. B. Jakobsen · L. Engebretsen $(\varangle)$

Orthopaedic Center, Ullevaal University Hospital and Medical

School, University of Oslo, 0407 Oslo, Norway

e-mail: lars.engebretsen@medisin.uio.no

A. M. E. Watsend

e-mail: ame.watsend@gmail.com; a.m.eriksen@studmed.uio.no

T. M. Ø. Osestad

e-mail: t.m.o.osestad@studmed.uio.no

R. B. Jakobsen

e-mail: r.b.jakobsen@gmail.com
} 